\title{
ORIGINAL
}

\section{Pharmacokinetics of Procainamide in Japanese Subjects}

\author{
Keiichi SHIMAMURA* \\ (Received on 30 Octover 1978) \\ * 1 st Department of Pharmacology, Hokkaido University School of \\ Medicine
}

\begin{abstract}
Summary
The present study was undertaken to elucidate the pharmacokinetics of procainamide (PA) in 4 Japanese who were found to be so-called fast acetylators. PA was injected intravenously and the serum concentrations of PA and N-acteylprocainamide (NAPA) were determined, following which the pharmacokinetic parameters of PA were calculated. In this study, it was found that the elimination rate constant $\left(\mathrm{k}_{\beta}\right)$ ranged from 0.22 to $0.43 \mathrm{hr}^{-1}$, the apparent volume of distribution ( $\mathrm{Vd}$ area) ranged from 1.80 to $3.57 \mathrm{l} / \mathrm{kg}$, body clearance $(\mathrm{Clb})$ ranged from 0.65 to 1.39 $1 / \mathrm{kg} / \mathrm{hr}$, and the area under the curve (AUC) ranged from 2.99 to $5.22 \mu \mathrm{g} / \mathrm{hr} / \mathrm{ml}$. Even after repeated oral administration to Japanese subjects, the serum concentration of PA did not reach the therapeutic range recommended by previous workers, while on the other hand, a remarkable increase in serum concentration of NAPA accompanied by the equilibrium state of serum PA concentration was noted. From the present results, it was suggested that the serum concentrations of both PA and NAPA should be taken into consideration in order to evaluate the antiarrhythmic effect after PA administration to Japanese subjects, most of whom are fast acetylators.
\end{abstract}

Key Words: Procainamide, Pharmacokinetics, N-acetylprocainamide, Fast acetylator, Japanese

PA is an antiarrhythmic agent in wide use. Recently however, NAPA, the main metabolite of PA, has also been revealed to have an antiarrhythmic effect. It has been reported that there exists an individual difference in the ac-

* Kita-ku, Sapporo 060, Japan tivity of liver N-acetyltransferase, which metabolizes PA to NAPA. As a result of research on isoniazid which is metabolized by the same enzyme, it has been revealed that in the majority of Japanese this enzyme is highly active. (Sunahara, S. et al., 1961; Dufour, A. P. et al., 1964). Thus it may be surmized that when PA is 
administered to Japanese, the serum concentration of NAPA would also be high. However no report is available in the literature concerning the pharmacokinetics of PA in Japanese fast acetylators. In the present work, attention was focused on the following two points. First, an investigation of the pharmacokinetic parameters of PA after intravenous and oral administration of PA in the Japanese fast acetylators was carried out, and then an attempt was made to determine the serum concentrations of PA and NAPA after repeated oral administration of PA in the same subjects.

\section{Methods and Materials}

Each of the 4 healty male subjects (body weight $60-80 \mathrm{~kg}$ ) received PA on 3 separate occasions at least one month apart. They were free from any drug for at least 3 days prior to each study. Blood samples were drawn from an antecubital vein using a secured i. v. catheter and collected without adding anticoagulant. Blood samples were centrifuged and the serum was stored at $-20^{\circ} \mathrm{C}$ for assay.

1) Intravenous injection

Four subjects received $250 \mathrm{mg}$ of PA-HCI by intravenous injection over a period of $2.5 \mathrm{~min}$. Blood samples were collected at 5, 15, 30, and $45 \mathrm{~min}$, and $1,1 \frac{1}{2}, 2,2 \frac{1}{2}, 3,4,5,6$, and $8 \mathrm{hr}$ after the end of injection. Twenty-four hour urine specimens were collected after the drug administration and were stored at $-20^{\circ} \mathrm{C}$

2) Single-dose oral administration

The four subjects fasted for at least $12 \mathrm{hr}$ before the study and continued to fast $2 \mathrm{hr}$ after administration of the drug. Five hundred $\mathrm{mg}$ of PA-HCI (Amisalin) were administered. Blood samples were collected at 15,30 , and $45 \mathrm{~min}$, and $1,1 \frac{1}{2}, 2,3,4,6,8$, and $12 \mathrm{hr}$ after administration.
3) Repeated oral administration

Three subjects fasted overnight. According to the method of Koch-Weser, approximately $12 \mathrm{mg} / \mathrm{kg}$ of PA was administered orally as a loading dose (Koch-Weser, J., 1974). As a maintenance dose, approximately $6 \mathrm{mg} / \mathrm{kg}$ of PA was thereafter given orally 3 times. the dosage interval was calculated using the biological half-life of PA for each subject. Ingestion of food was avoided for over 20 min after the first oral administration of the maintenance dose. Blood samples were drawn immediately prior to each administration and $1 \mathrm{hr}$ after administration. In addition, blood samples were also drawn $2 \sim 3 \mathrm{hr}$ after the last oral administration.

\section{4) Determination of PA and NAPA}

Measurement of PA and NAPA in the blood and urine were made after the method of Matsusik and Gibson (Matusik, E. and Gibson, T. P., 1975). In the case of the urine samples, the urine was diluted 20 -fold with distilled water before being used for determination.

To $1 \mathrm{ml}$ of the samle or standard, $0.25 \mathrm{ml}$ of $2.5 \mathrm{~N} \mathrm{NaOH}$ and $0.5 \mathrm{~g}$ of $\mathrm{NaCl}$ was added and mixed gently, after which $10 \mathrm{ml}$ of benzene was added and shaken vigorously for $15 \mathrm{~min}$. This was centrifuged for $10 \mathrm{~min}$ at $2,000 \mathrm{rpm}$, following which $8 \mathrm{ml}$ of the benzene layer were transfered to a different tube. After adding $3 \mathrm{ml}$ of $0.1 \mathrm{~N} \mathrm{HCl}$, the mixture was shaken and centrifuged again and the benzene layer was removed by aspiration. Finally a fluorometric assay was conducted using a Hitachi type 204 spectrofluorometer. The concentration of NAPA in the acid phase ( $\mathrm{pH} 1.0$ ) was first measured at the maximum activation wavelength of $288 \mathrm{~nm}$ and the maximum fluorescence wavelength of $340 \mathrm{~nm}$. The solution was then adjusted to $\mathrm{pH} 11$ with $2.5 \mathrm{~N} \mathrm{NaOH}$ using a $\mathrm{pH}$ 
meter and measurement of PA was made at the maximum activation wavelength of $298 \mathrm{~nm}$ and maximum fluorescence wavelength of $354 \mathrm{~nm}$.

In the calculation of pharmacokinetic parameters, a Canon Canola SX 350 personal computer was used.

\section{Results}

A linear reltionship existed between fluorescent intensity and concentration, ranging from 0.1 to $10 \mu \mathrm{g} / \mathrm{ml}$ in both PA and NAPA. The recovery of both PA and NAPA was approximately $90 \%$.

1) The serum concentration curves of PA and

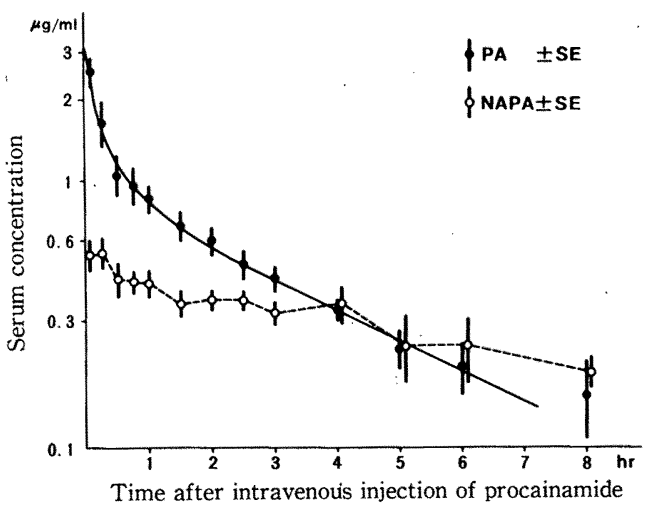

Fig. 1 Semilogarithmic plot of serum concentration of procainamide and $\mathrm{N}$ acetyl procainamide following intravenous indection of procainamide $250 \mathrm{mg}$.

Table 1 Pharmacokinetic Paramaters of Procainamide after $250 \mathrm{mg}$ Intravenously

\begin{tabular}{|c|c|c|c|c|c|c|c|}
\hline \multicolumn{2}{|c|}{ Parameter } & \multirow{2}{*}{$\frac{Y . U .}{2.36}$} & \multirow{2}{*}{$\frac{Y . K .}{3.10}$} & \multirow{2}{*}{$\frac{1.5 .}{1.40}$} & \multirow{2}{*}{$\frac{\text { K. S. }}{1.00}$} & \multicolumn{2}{|c|}{ Mean $\pm(S E)$} \\
\hline A & $\mu \mathrm{g} / \mathrm{ml}$ & & & & & 2.00 & $(0.47)$ \\
\hline B & & 0.94 & 1.95 & 0.97 & 1.04 & 1.23 & $(0.24)$ \\
\hline$\alpha$ & $\mathrm{hr}^{-1}$ & 10.93 & 5.54 & 3.79 & 4.21 & 6.12 & $(1.65)$ \\
\hline $\boldsymbol{\beta}$ & $\mathrm{hr}^{-1}$ & 0.29 & 0.43 & 0.22 & 0.39 & 0.33 & $(0.05)$ \\
\hline$T_{1 / 2} \beta$ & hr & & 1.61 & 3.15 & 1.78 & 2. 23 & $(0.35)$ \\
\hline$v_{1}$ & $\mathrm{~L} / \mathbf{k g}$ & 1.01 & 0.80 & 1.32 & 2.04 & 1.29 & $(0.27)$ \\
\hline & $\mathrm{L} / \mathbf{k g}$ & & 0.86 & 1.43 & 1.37 & 1.44 & $(0.26)$ \\
\hline Vd area & $\mathrm{L} / \mathbf{k g}$ & 2.62 & 1.80 & 2. 95 & 3.57 & 2.74 & $(0.37)$ \\
\hline Vd ss & L/kg & 3. 12 & 1.66 & 2.75 & 3.41 & 2. 74 & $(0.38)$ \\
\hline$K_{12}$ & $h r^{-1}$ & 6.94 & 2.58 & 1.83 & 1.56 & 3.23 & (1. 26) \\
\hline$K_{21}$ & $\mathrm{hr}^{-1}$ & 3. 32 & 2. 41 & 1.69 & 2. 34 & 2. 44 & $(0.34)$ \\
\hline Kel & $\mathrm{hr}^{-1}$ & 0.96 & 0.98 & 0.50 & 0.70 & 0.79 & $(0.11)$ \\
\hline$A \cup C$ & $\mu \mathrm{g} \mathrm{hr} / \mathrm{ml}$ & 4. 39 & 5. 22 & 4. 81 & 2.99 & 4. 35 & $(0.48)$ \\
\hline Clb & $\mathrm{L} / \mathbf{k g} / \mathbf{h r}$ & 0.76 & 0.77 & 0.65 & 1.39 & 0.89 & $(0.17)$ \\
\hline
\end{tabular}

NAPA following intravenous injection of 250 mg of PA are shown in Fig. 1. The decline in the serum concentration of PA exhibited a biexponential pattern with the distribution phase being completed after $30 \mathrm{~min}$.

Using a two compartent model, the pharmacokinetic parameters for PA were calculated as shown in Table 1. The biological half-life ranged from 1.61 to $3.15 \mathrm{hr}(2.23 \pm 0.35)$ and the area under the curve (AUC) calculated by the trapezoidal rule ranged from 2.99 to $5.22 \mu \mathrm{g} \mathrm{hr} /$ $\mathrm{ml}$.

Renal clearance $(\mathrm{Cl} r)$ of PA was estimated by the following equation :

$\mathrm{Cl}_{\mathrm{r}}=\frac{\text { total amount excreted as PA in } 24 \mathrm{hr} \text { urine }}{\mathrm{AUC}_{0-24 \mathrm{hr}}}$

The $\mathrm{Cl}$ r of PA ranged from 441 to $989 \mathrm{ml} /$ min $(653 \pm 118)$ indicating tubular secretion. NAPA was already present at a level of 0.41 $\sim 0.74 \mu \mathrm{g} / \mathrm{ml} 5 \mathrm{~min}$ after intravenous injection of PA and thereafter declined at a half-life of $3.54 \sim 6.36 \mathrm{hr}(5.34 \pm 0.69)$. The AUC of NAPA ranged from 2.34 to $6.66 \mu \mathrm{g} \mathrm{hr} / \mathrm{ml}$. In the $24-\mathrm{hr}$ urine specimen collected following intravenous injection, $116 \sim 184 \mathrm{mg}$ (mean $=162.3 \mathrm{mg}$ ) of PA and $40 \sim 60 \mathrm{mg}$ (mean $=54.5 \mathrm{mg})$. of NAPA were detected.

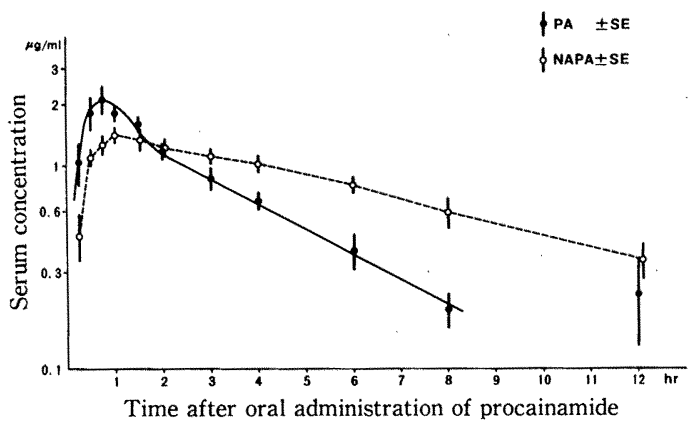

Fig. 2 Semilogarithmic plot serum concentration of procainamide and $\mathrm{N}$ acetylprocaininamide following oral administration of $500 \mathrm{mg}$ of procainamide. 
Table 2 Pharmacokinetic Parameters of Procainamide after $500 \mathrm{mg}$ Oral Administration

\begin{tabular}{|c|c|c|c|c|c|c|c|}
\hline \multicolumn{2}{|c|}{ Parameter } & \multirow{2}{*}{$\frac{Y . U .}{0.27}$} & \multirow{2}{*}{$\frac{Y . K \text {. }}{0.38}$} & \multirow{2}{*}{$\frac{1 . S .}{0.34}$} & \multirow{2}{*}{$\frac{\text { K. S. }}{0.22}$} & \multicolumn{2}{|c|}{ Mean $\pm(S E)$} \\
\hline$\beta$ & $\mathrm{hr}^{-1}$ & & & & & 0.30 & $(0.04)$ \\
\hline$T_{1 / 2} \beta$ & hr & 2.61 & 1.85 & 2.04 & 3.16 & 2.42 & $(0.30)$ \\
\hline Vdarea & $\mathbf{L} / \mathbf{k g}$ & 3. 28 & 3. 20 & 3.10 & 4.73 & 3.58 & $(0.39)$ \\
\hline AUC & $\mu \mathrm{g} \mathrm{hr} / \mathrm{ml}$ & 7.53 & 6.63 & 5.92 & 8.00 & 7.02 & $(0.46)$ \\
\hline Clb & $\mathrm{L} / \mathbf{k g} / \mathbf{h r}$ & 0.86 & 1.22 & 1.06 & 1.04 & 1.05 & $(0.07)$ \\
\hline
\end{tabular}

Case 1. Y. U. $\hat{\delta} 42 \mathrm{yr}$. Body meight $75 \mathrm{~kg}$. T $1 / 2 \beta 2.5 \mathrm{hr}$

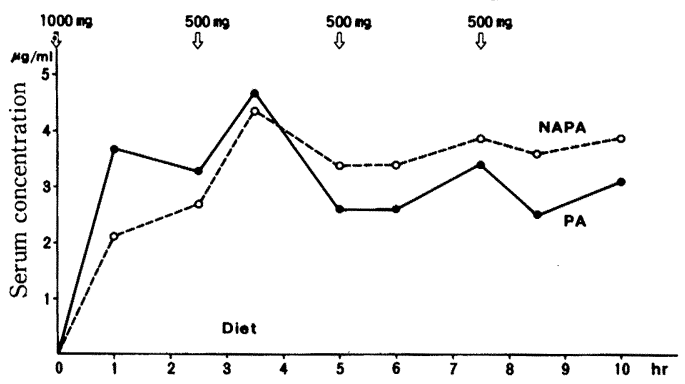

Case2.Y. K. $\$ 26 y r$. Body weight $62 \mathrm{~kg}$. T $1 / 2 \beta 1.7 \mathrm{hr}$

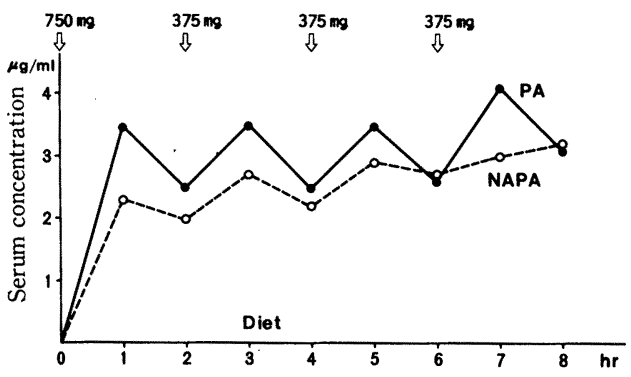

Case 3. I. S. $\hat{\delta} 32 \mathrm{yr}$. Body weight $80 \mathrm{~kg}$. T $1 / 2 \beta 2.6 \mathrm{hr}$

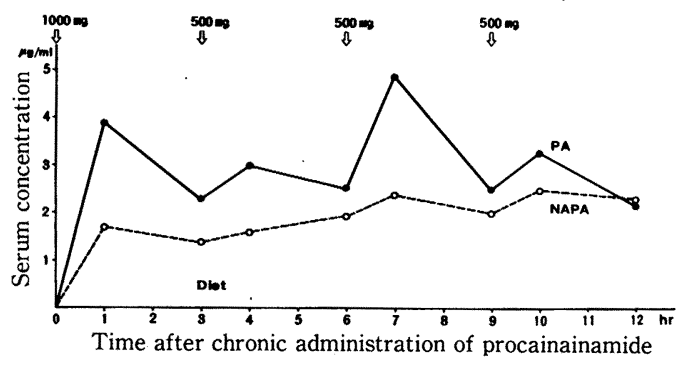

Fig. 3
2) The serum concentration curves of PA and NAPA after oral administration of $500 \mathrm{mg}$ of $\mathrm{PA}$ are shown in Fig. 2. Following oral administration of PA, the peake seak serum level was reached in $60 \mathrm{~min}$, its concentration ranging from 1.67 to $3.46 \mu \mathrm{g} / \mathrm{ml}$. Thereafter the biological half-life of the elimination phase ranged from 1.85 to $3.16 \mathrm{hr}(2.42 \pm 0.30)$. The AUC ranged from 5.92 to $8.00 \mu \mathrm{g} \mathrm{hr} / \mathrm{ml}(7.02 \pm$ 0.46) (Table 2). At 15 min after PA administration, NAPA was found at a concentration of $0.12 \sim 0.81 \mu \mathrm{g} / \mathrm{ml}$. The peak serum level of NAPA was reached within $3 \mathrm{hr}$ and its concentration ranged from 1.24 to $1.83 \mu \mathrm{g} / \mathrm{ml}$. Then the concentration curve of NAPA declined at a biological half-life ranging from 2.78 to $6.28 \mathrm{hr}$ $(5.08 \pm 0.79)$. It was noted that $3 \mathrm{hr}$ after oral administration of PA the concentration of NAPA was higher than that of PA, and at $6 \mathrm{hr}$, the ratio of NAPA against (PA plus NAPA) ranged from 55.2 to $74.5 \%(65.5 \pm 5.2)$. The AUC of NAPA was $8.34 \sim 12.08 \mu \mathrm{g} \mathrm{hr} / \mathrm{ml}$, which was larger than that of $\mathrm{PA}$.

3) A comparison was run between the data for PA after oral administration and after intravenous injection of the drug. Bioavailability (F) was calculated by the following equation :

$$
F=\frac{\text { AUC }_{\text {p.o. }}}{\text { AUC }_{\text {i.v. }}} \times \frac{\text { dose }_{\text {i.v. }}}{\text { dose }_{\text {p.o. }}} \times \frac{T_{\frac{1}{2} \text { i.v. }}}{T_{\frac{1}{2} \text { p.o. }}}
$$

The value of $\mathrm{F}$ ranged from 55.9 to $94.5 \%$ $(76.2 \pm 7.9)$.

4) When repeated oral administration of PA was done at intervals close to its half-life in each subject at a loading dose of $15 \mathrm{mg} / \mathrm{kg}$ and at a maintenance dose of $6 \mathrm{mg} / \mathrm{kg}$, the steady -state serum concentration of PA fluctuated from 2.2 to $4.9 \mu \mathrm{g} / \mathrm{ml}$. The serum concentration of NAPA ranged from 1.4 to $4.4 \mu \mathrm{g} / \mathrm{ml}$, but a tendency to increase with an increase in the number of doses was noted (Fig. 3). 


\section{Discussion}

The degree of acetylation can be conveniently characterized by the ratio of serum concentration of NAPA against serum concentration of PA plus NAPA : NAPA/(PA+NAPA). Frislid et al. reported (Frislid, K. et al. 1976) that $6 \mathrm{hr}$ after a single oral administration of $\mathrm{PA}$, a value of over $50 \%$ for the serum ratio NAPA/(PA + NAPA) was termed "fast acetylator". In this study, it was noted that the ratios in all four cases were over 50\% (55.2 74.5\%) 6 $\mathrm{hr}$ after oral administration. Using the criterion of Frislid et al. these subjects are to be classified as fast acetylators. As a result of research work on the acetylation of isoniazid, it has been reported that the majority of Europeans and Americans are slow acetylators. In contrast, the majority of Japanese are known to be fast acetylators.

The report of Gibson et al. may be summarized as follows (Gibson, T. R. et al., 1975) : with 10 slow acetylators, $53.1 \%$ of orally administered $\mathrm{PA}$ was recovered as unchanged $\mathrm{PA}$ and $12.4 \%$ was recovered as NAPA in the $96 \mathrm{hr}$ urinary specimens; however, with 4 fast acety. lators, $49.8 \%$ of the PA admministered was recovered as unchanged $\mathrm{PA}$ and $23.4 \%$ was recovered as NAPA under the same experimental conditions. As the result of the present work with Japanese subjects, $64.9 \pm 6.2 \%$ of intravenously administered PA was recovered as unchanged PA and $21.8 \pm 0.7 \%$ was recovered as NAPA in the $24 \mathrm{hr}$ urine specimens. The increased excretion of NAPA by fast acetylators may be accordingly seen. With regard to the increased excretion of NAPA, the present results coincide with Gibson's paper. Using the serum concentration of PA after an intravenous injection of $250 \mathrm{mg}$, the pharmacokinetic parameters for Japanese were calculated and were compared with those of Americans and Europeans (Koch-Weser, J., 1971a ; Galeazzi, R. L. et al., 1976). In the present experiment, the values for $\mathrm{K}_{\beta}$, $\mathrm{Vd}$ area, $\mathrm{Vd} \mathrm{ss}, \mathrm{Clb}$, and $\mathrm{Clr}$ were somewhat higher in Japanese subjects. Further, in the present work the $\mathrm{AUC}_{0-\infty}$ of PA following intravenous injection of PA was markedly smaller than that of Europeans (Graffner, C. et al., 1975). All subjects examined in this study were fast acetylators and PA was metabolized to NAPA to a larger extent than in Europeans.

Koch-Weser in his work (Koch-Weser, J. et al., 1971b) with Americans reported that under a loading doses of $12 \mathrm{mg} / \mathrm{kg}$ of PA and maintenance doses of $6 \mathrm{mg} / \mathrm{kg}$ of PA orally administered every $3 \mathrm{hr}$, the PA serum concentration may be maintained to within a therapeutic range of $4 \sim 8 \mu \mathrm{g} / \mathrm{ml}$. In the present work, serum PA ranged from 2.2 to $4.9 \mu \mathrm{g} / \mathrm{ml}$. Accordingly, the serum levels of PA in this study were clearly lower than in Koch-Weser's paper. Regarding bioavailability of PA, the result of this study did not prove very different from those previously reported. The discrepancy between the present report and Koch-Weser's report would be with respect to the fact that in the fast acetylators in this study, the acetylation of PA into NAPA was greater than that of Europeans and Americans and that the serum concentration of PA after repeated oral administrations cannot be sufficiently maintained. On the other hand, in this study the serum concentration of NAPA showed a tendency to increase after the repeated oral administration of PA. Thus if administration of PA is repeated over a longer period than that studied, it may be supposed that the serum concentration of NAPA may eventually exceed that of PA. 
According to Shudo (Shudo, I., unpublished data) as a result of his research on American subjects who were slow acetylators, even when a prolonged oral administration of PA every 4 $\mathrm{hr}$ was made, the serum concentration of NAPA was invariably lower than that of PA. In the author's opinion, distinguishing between slow acetylators and fast acetylators is of the utmost importance in prolonged administration. It has been reported that NAPA has antiarrhythmic effect (Drayer, D. E. et al., 1974), and also that the relative potency of the antiarrhythmic effect of NAPA varied from 30 to 100\% compared with PA (Drayer, D. E. et al., 1974 ; Bagwell, E. E. et al., 1976 ; Elson, J. et al., 1975 ; Lee, W-K. et al., 1976 ; Atkinson, A. J. Jr. et al., 1977). Further, the biological half-life of NAPA is $6 \mathrm{hr}$ (Strong, J. M. et al., 1975) and the protein binding of NAPA is reported to be slightly less than that of PA (Koch-Weser, J., 1971a ; Reidenberg, M. M. et al., 1975 ; Bagwell, E. E. et al., 1974). Based on the facts described above, in the case of prolonged administraion of PA to fast acetylators, the antiarrhythmic effect of NAPA cannot be overlooked. When $\mathrm{PA}$ is adminstered to patients with arrhythmia who are fast acetylators, the antiarrhythmic effect of NAPA should definitely be considered when the optimal dosage schedule is determined.

\section{Acknowledgment}

The author want to express his gratitude to Yoshiro Uchiyama for his excellent technical assistance, and to Isami Shudo, Yuichi Koike and Hideya Saito for their valuable advice and encouragement.

\section{References}

Atkinson, A. J. Jr., Lee, W-K., Quinn, M. L.,
Kushner, W., Nevin, M. J. and Strong, J. M. : Dose ranging trial of $\mathrm{N}$-acetylprocainamide in patients with premature ventricular contractions. Clin. Pharmacol. Ther., $21: 575-587$ (1977).

Bagwell, E. E., Drayer, D. E., Reidenberg, M. M. and Pruett, J. K. : Effect of the N-acetyl metabolite of procainamide on transmembrane action potentials of canine His-Purkinje cells. Clin. Res., 22 : 676-A (1974).

Bagwell, E. E., Walle, T., Drayer, D. E., Reidenberg, M. M. and Pruett, J. K. : Correlation of the electrophysiological and antiarrhythmic properties of the $\mathrm{N}$-acetyl metabolite of procainamide with plasma and tissue drug concentrations in the dog. J. Pharmacol. Exp. Ther., 197 : 38-48 (1976).

Drayer, D. E., Reidenberg, M. M. and Sevy, R. $\mathrm{W},: \mathrm{N}$-acetylprocainamide; an active metabolite of procainamide. Proc. Soc. Exp. Biol. (N. Y.)., $146: 358-363$ (1974).

Dufour, A. P., Knight, R. A. and Harris, H. W. : Genetics of isoniazide metabolism in Caucasian, Negro and Japanese population. Science, $145: 391$ (1964).

Elson, J., Strong, J. M., Lee, W-K. and Atkinson, A. J. Jr. : Antiarrhythmic potency of $\mathrm{N}$-acetylprocainamide. Clin. Pharmacol. Ther., 17 : 134-140 (1975).

Frislid, K., Berg, M., Hansteen, V. and Lunde, P. $\mathrm{K}$. : Comparison of the acetylation of procainamide and sulfadimidine in man. Europ. J. Clin. Pharmacol., 9 : 433-438 (1976).

Galeazzi, R. L., Benet, L. Z., and Sheiner, L. B. : Relationship between the pharmacokinetics and pharmacodynamics of procainamide. Clin. Pharmacol. Ther., 20 : 278-289 (1976).

Gibson, T. P., Matusik, J., Matusik, E., Nelson, H. A., Wilkinson, J. and Briggs, W. A. : Acetylation of procainamide in man and its relationship to isonicotinic acid hydrazide acetylation phenotype. Clin. Pharmacol. Ther. 17 : 395-399 (1975).

Graffner, C., Johnsson, G. and Sjögren, J. : Pharmacokinetics of procainamide intravenously and orally as conventional and slow-release tablets. Clin. Pharmacol. Ther. $17: 414-423$ (1975).

Koch-Weser, J. : Pharmacokinetics of procainamide in man. Ann. N. Y. Acad. Sci., $179: 370$ -382 (1971a). 
Koch-Weser, jJ. and Klein, S. W. : Procainamide dosage schedules, plasma concentrations and clinical effects. J. A. M. A., 215 : 1454-1460 (1971b).

Koch-Weser, J. : Clinical application of the pharmacokinetics of procainamide. Cardiovascular Clinics., 6 : 63-75 (1974).

Lee, W-K., Strong, J. M., Kehoe, R. F., Dutcher, J. S. and Atkinson, A. J. Jr. : Antiarrhythmic efficiency of $\mathrm{N}$-acetylprocainamide in patients with premature ventricular contractions. Clin. Pharmacol. Ther. 19 : 508-514 (1976).

Matusik, E. and Gibson, T. P. : Fluorometric assay for N-acetylprocainamide. Clin. Chem.,
21 : 1899-1902 (1975).

Reidenberg, M. M., Drayer, D. E., Levy, M. and warner, H. : Polymorphic acetylation of procainamide in man. Clin. Pharmacol. Ther., 17 : 722-730 (1975).

Shudo, I. : unpublished data

Strong, J. M., Dutcher, J.S., Lee, W-K. and Atkinson, A. J. Jr. : Pharmacokinetics in man of the $\mathrm{N}$-acetylated metabolite of procainamide. J. Pharmacokinet. Biopharm., 3 : 223-235 (1975).

Sunahara, S., Urano, M. and Ogawa, M. : Genetical and geografic studies on isoniazid inactivation. Science, 134 : 1530 (1961). 